\title{
DE
} DE GRUYTER OPEN

Arch. Min. Sci. 62 (2017), 4, 871-891

Electronic version (in color) of this paper is available: http://mining.archives.pl

DOI 10.1515/amsc-2017-0060

TU HONG-SHENG $*, * *$, TU SHI-HAO*,**, ZHANG CUN***\#, ZHANG LEI*,**, ZHANG XIAO-GANG*,**

\section{CHARACTERISTICS OF THE ROOF BEHAVIORS AND MINE PRESSURE MANIFESTATIONS DURING THE MINING OF STEEP COAL SEAM}

\section{CHARAKTERYSTYKI ZACHOWAŃ MATERIALU SKALNEGO I WZROSTY CIŚNIENIA W TRAKCIE URABIANIA ZLÓŻ WĘGLA O DUŻYM NACHYLENIU}

\begin{abstract}
A steep seam similar simulation system was developed based on the geological conditions of a steep coal seam in the Xintie Coal Mine. Basing on similar simulation, together with theoretical analysis and field measurement, an in-depth study was conducted to characterize the fracture and stability of the roof of steep working face and calculate the width of the region backfilled with gangue in the goaf. The results showed that, as mining progressed, the immediate roof of the steep face fell upon the goaf and backfilled its lower part due to gravity. As a result, the roof in the lower part had higher stability than the roof in the upper part of the working face. The deformation and fracture of main roof mainly occurred in the upper part of the working face; the fractured main roof then formed a "voussoir beam" structure in the strata's dip direction, which was subjected to the slip- and deformation-induced instability. The stability analysis indicated that, when the dip angle increased, the rock masses had greater capacity to withstand slip-induced instability but smaller capacity to withstand deformation-induced instability. Finally, the field measurement of the forces exerted on the hydraulic supports proved the characteristics of the roof's behaviors during the mining of a steep seam.
\end{abstract}

Keywords: steep coal seam; similar simulation; mining pressure; gangue backfilling; "voussoir beam" structure

Opracowano układ do symulacji urabiania złóż węgla o dużym nachyleniu w oparciu o warunki geologiczno-górnicze w kopalni węgla Xintie. W oparciu o wyniki podobnych symulacji, analiz teoretycznych i pomiarów terenowych określono skalę spękań skał stropowych nad stromo nachylonym wyrobiskiem oraz stabilność skała stropowych, a także obliczono szerokość obszaru w zrobach podsadzanego skałą płonną. Wyniki badań wskazały, że wraz z postępem prac wydobywczych, strop bezpośredni ponad stro-

* STATE KEY LABORATORY OF COAL RESOURCES AND SAFE MINING, CHINA UNIVERSITY OF MINING AND TECHNOLOGY, XUZHOU, JIANGSU 221116, CHINA

** KEY LABORATORY OF DEEP COAL RESOURCE MINING, MINISTRY OF EDUCATION, CHINA UNIVERSITY OF MINING AND TECHNOLOGY, XUZHOU, JIANGSU 221116, CHINA

*** SCHOOL OF RESOURCE AND SAFETY ENGINEERING, CHINA UNIVERSITY OF MINING AND TECHNOLOGY (BEIJING), BEIJING 100083, CHINA;

\# Corresponding author: cumt_zc@163.com 
mym wyrobiskiem obsunął się do zrobów wskutek działania sił ciężkości, wypełniając ich dolną część W rezultacie, strop w niższej części wyrobiska wykazywał lepszą stabilność niż skały stropowe w jego górnej części. Odkształcenia i pęknięcia stropu zasadniczego zarejestrowano głównie w górnych partiach wyrobiska, spękany strop zasadniczy utworzył tam układ belki klińcowej nachylonej w kierunku upadowej, niestabilny pod wpływem uskoku i wskutek oddziałujących deformacji. Analiza stabilności stropu wykazała, że wraz ze wzrostem kąta nachylenia, wzrasta wytrzymałość górotworu na niestabilność wskutek obsuwania się w kierunku nachylenia, z kolei maleje jego wytrzymałość na oddziaływania odkształceń. Ponadto, wykonane pomiary sił działających na podpory hydrauliczne potwierdziły wzorce zachowania się górotworu w trakcie prac wydobywczych w złożach o dużym nachyleniu.

Słowa kluczowe: wyrobiska o dużym nachyleniu, symulacje, ciśnienie, podsadzka ze skały płonnej, układ belki klińcowej

\section{Introduction}

Steep seams refer to coal seams dipping at angles larger than $45^{\circ}$. In a steep coal seam, the stress applied to the roof by surrounding rocks can be divided into two components: the normal stress perpendicular to the strata, and the shear stress parallel to the strata (Yang et al., 2014; Liu et al., 2015), larger than the normal stress. Due to the large dip angle, the immediate roof in the upper part of the working face tends to collapse upon the goaf and backfill its lower space, forming a support for the lower roof while the upper roof is left suspended (Zaitsev, 1971; Ren et al., 2015; Deb et al., 2009). As a result, the overlying strata are subject to asymmetric stress in the dip direction (Fig. 1) and thus undergo asymmetric bed separation and caving, bringing about difficulty with surrounding rock management.

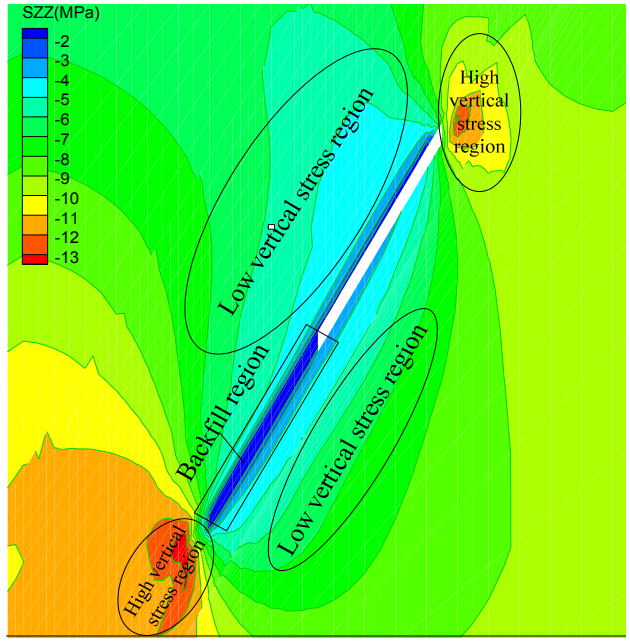

Fig. 1. Stope's stress distribution rule

A great deal of research has been conducted on the mining of steep seams. Through field measurement, Kulakov (1995) has studied the characteristics of mine pressure manifestations caused by mining of steep seams. Bodi (1997) has discussed the unmanned mining technique for 
steep seams and the related problems with surrounding rock stability control. Gao et al. (2004) has studied how the overlying strata moved under the influence of repeated mining of a steep seam group. Wang et al. (2009) has revealed the discontinuity in the deformation and movement of rocks in the research on the fracturing mechanisms of the roof and floor of a steep coal face. Li et al. (2010) has found that the first cave-in and periodic cave-ins of the roof of a steep seam all occurred in the middle and upper parts of the working face. Ju et al. (2008) has researched how the overlying strata fractured during the slicing of hard roof of a steep, ultra-thick coal seam. Based on the theory of elastic thin plate, Yin et al. (2006) has established an equation describing the maximum deflection of roof and found the location where the maximum deflection occurred. Wu et al. (2010a, b, 2012) has analyzed the stress variation in the surrounding rocks as the steep working face advanced. They found that the rock blocks that had fallen from the roof above a steeply-dipping seam did not form a regular structure along the direction of advance of the working face, but were stacked up into along-dip and anti-dip piles along the width of the working face. In this direction, the piles were asymmetrically distributed at both ends of the face rather than forming a continuous structure to protect the stope below. Luo et al. (2016) has analyzed the characteristics of stress arch in the surrounding rocks during steeply dipping seam mining by numerical modeling. They found that the stress arch shell was symmetrical along the direction of advance of the working face and asymmetrical along the dip direction, and after the roof fractured and caved in, the caved gangue tended to slide down to the lower part of the goaf. However, this study did not analyze the widths of the backfills of caved roof rocks that showed different mechanical behaviors and the factors influencing them. Li and Liu (2016) has mechanically modeled the roof above a steeply dipping coal seam as a clamped beam along the dip direction of the face and analyzed the forces acting on different locations along the roof. This analysis focused on mechanical deformation occurring before roof fractured and did not take into account the support provided by the gangue filling the goaf's lower part. Xie et al. (2012) has created a fractured roof-support interaction model for a coal face in a steeply dipping seam. This study revealed three modes of support failure, including compression, slip and toppling, and provided a method for calculating reasonable support resistance for working faces in steeply dipping seams. However, it only analyzed discrete caved rock masses from the roof and failed to take into account the influence of interaction between rock blocks that were in contact.

According to the review above, previous studies generally demonstrate that the caved rock masses in a goaf of a steeply dipping seam are unlikely to form structures along the direction of advance of the coal face, but tend to form structures along the dip direction, and such structures have a great influence on mining. This has been a focus of research on steep seam mining. However, the findings of these studies are more or less incapable of explaining the following mine pressure manifestations during steep seam mining: (1) the supports along the lower part of a working face are subjected to smaller forces than those along the upper part; (2) the roof cave-ins in different parts of a face are not synchronous; (3) the face supports in a steeply dipping seam experience much smaller forces than those in a nearly horizontal seam at the same burial depth and under similar conditions. An investigation of how the mine roof fractures and loses stability should be made before undertaking the tasks of selecting the model of hydraulic roof support, interpreting the characteristics of the mine pressure manifestations, and regulating the surrounding rocks in a mine. Therefore, this research was conducted to investigate how the immediate roof collapsed and backfilled the goaf in the steep coal seam and on the stability of the "voussoir beam" structure formed from the broken main roof. 


\section{Experimental apparatus}

Similar material modeling experiment chosen for this analysis is intended for laboratory analysis of the characteristics of discontinuous fracture and caving of the rock and coal masses that are under the influence of mining (Niu et al., 2015; Wu et al., 2014). Because of its effectiveness, it has been widely used in studies on the deformation, movement, and failure of the strata in coal mines. Moreover, it has played an important role in the research, planning, and experiments in mining engineering (Zhang et al., 2013).

During modeling, the task of laying steep strata was difficult since the materials on a steep surface could easily slip down. Additionally, the strata in the model would undergo serious deformation during air drying, which may increase experimental error and reduce the reliability of data. To tackle this problem, the model support was designed to be rotary so that it can be adjusted before experiment to a state that allows strata laying in a horizontal position to obtain the equivalent real dip angle of strata. In this way, the slip and deformation of materials were avoided. Then the model support was rotated to the working face mining state after the strata were air-dried. This method effectively facilitated the strata laying and the application of vertical loads. Fig. 2 displays the design of the model support. In the experiment, a PLC control system was used to rotate the model support, and hydraulic loading was employed to apply loads to the model evenly.
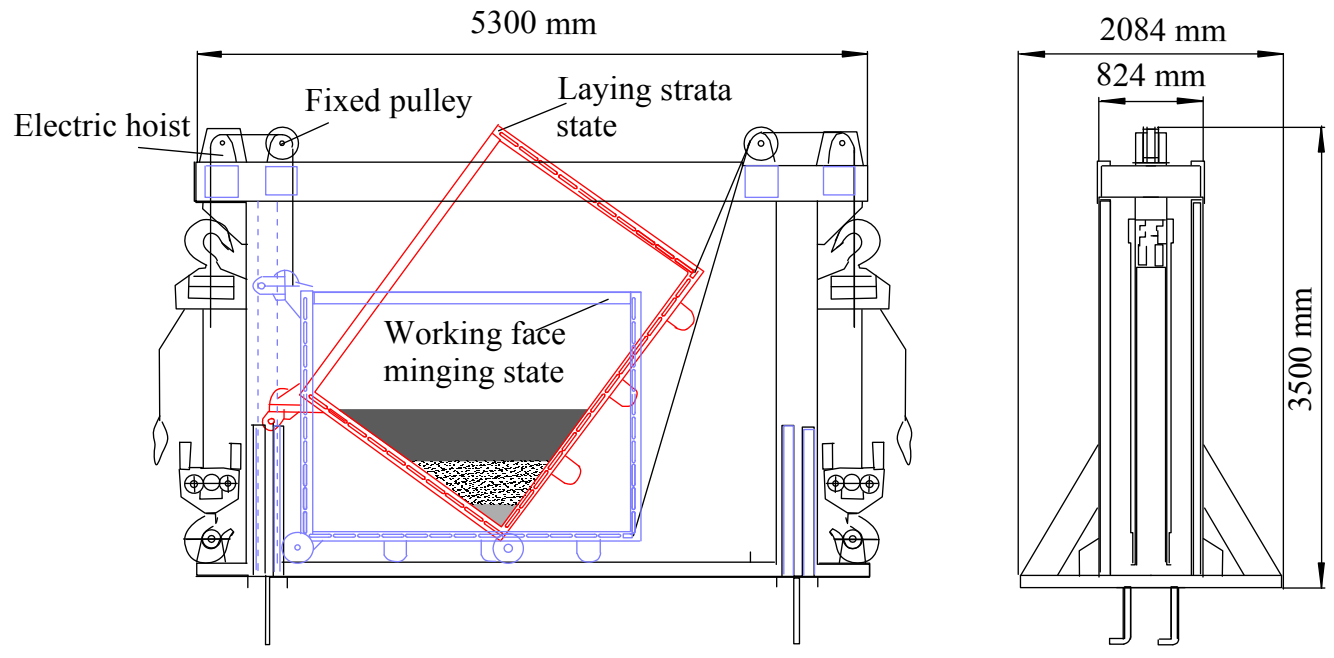

Fig. 2. Experimental system in steep coal seam

\section{Project overview and experimental method}

\subsection{Project overview}

In the Xintie Coal Mine run by the Qitaihe Company of Heilongjiang Longmay Mining Group, the mining process is undertaken mainly in the $49^{\#}{ }_{\text {lower }}$ steep seam, which is $2 \mathrm{~m}$ thick 
on average (Fig. 3). The elevation of the seam ranges from -141 to $-215 \mathrm{~m}$ and the elevation of the surface above it is $+211 \mathrm{~m}$. The seam has a Protodyakonov coefficient of 0.8 . Its dip angle is between $58^{\circ}$ and $62^{\circ}$, with an average of $60^{\circ}$. The working face is $84 \mathrm{~m}$ long in its dip direction and $551 \mathrm{~m}$ long along its strike. The seam is mined by fully-mechanized longwall mining along the strike, which involves the use of the MG2×125/580-WD coal-cutting machine, ZQY3600/12/26 hydraulic roof support, and SGZ-730/320 scraper chain conveyor.

\begin{tabular}{|c|c|c|c|c|c|c|c|}
\hline Number & Columnar & Name & Thickness/m & Number & Columnar & Name & Thickness/m \\
\hline 1 & & Carbon mudstone & 29.3 & 14 & & Mudstone & 0.9 \\
\hline 2 & & Gritstone & 24.3 & 15 & & Siltstone & 1 \\
\hline 3 & & Mudstone & 18.1 & 16 & & $49 \#$ lower steep seam & 2 \\
\hline 4 & & Medium sandstone & 21.5 & 17 & & Siltstone & 10 \\
\hline 5 & $=-\overline{-}$ & Fine sandstone & 26.7 & 18 & & Medium sandstone & 13.6 \\
\hline 6 & & Siltstone & 13.5 & 19 & & Gritstone & 10.4 \\
\hline 7 & & Gritstone & 6.4 & 20 & & Carbon mudstone & 16.1 \\
\hline 8 & $3 x$ & Mudstone & 11.7 & 21 & & Fine sandstone & 19.2 \\
\hline 9 & s.t. & Medium sandstone & 12.6 & 22 & & Medium sandstone & 19.3 \\
\hline 10 & & Fine sandstone & 14.3 & 23 & & Siltstone & 18.6 \\
\hline 11 & $\overline{3} \overline{1-F}$ & Gritstone & 5.1 & 24 & "E- & Mudstone & 20.5 \\
\hline 12 & H, & Fine sandstone & 1.3 & & & & \\
\hline 13 & 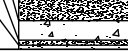 & Siltstone & 1.1 & & & & \\
\hline
\end{tabular}

Fig. 3. Geological columnar section

\subsection{Experimental method}

At present, there is still great difficulty in realizing complete visibility in similar simulation experiments (we have failed to develop a three-dimensional experimental platform with multi-scale imaging probes in the laboratory after multiple attempts, but the research continues).

As the dip angle of a steep seam is higher than $45^{\circ}$, the component of the force of gravity exerted on the roof along the dip direction is greater than the component perpendicular to the seam. While the latter is the main trigger for roof fracture, the former helps stabilize the roof along the dip direction and ensure the stability of the structure formed from broken roof. Therefore, the breaking length of the roof along the dip direction is often long. In a vertical plane parallel to the direction of advance of the face, the roof is controlled mainly by the force of gravity and undergoes no compressive stress parallel to the strata. As a result, along the direction of advance of the face, the roof has a short breaking length and is unlikely to constitute a structure after it fractures. This explains why the roof above a steeply dipping seam is more likely to form a structure along the dip direction. Therefore, simplifying the three-dimensional roof problem into a two-dimensional 
(planar) stress model will facilitate problem analysis and allow for qualitative conclusions to be drawn (Qian \& Shi, 2003).

The following parameters of the model were determined according to the actual conditions of the steep coal face in Xintie Coal Mine: the geometric similarity ratio was $C_{l}=1: 100$, similarity ratio of unit weight was $C_{r}=1.7: 2.7$, and dip angle of seam was $60^{\circ}$. During the similar simulation experiment, a stress gauge TSW-50 (range: $\pm 0.5 \mathrm{MPa}$; accuracy: $0.5 \% \mathrm{FS}, 1.0 \% \mathrm{FS}$; repeatability: $0.2 \% \mathrm{FS}, 0.4 \% \mathrm{FS}$; resolution: $0.01 \% \mathrm{FS}$ ) and a displacement gauge $\mathrm{GY}-1$ (range: $\pm 100 \mathrm{~mm}$; sensitivity coefficient: 2 ; applicable temperature range: $-35 \sim 60^{\circ} \mathrm{C}$; weight: $350 \mathrm{~g}$; length of lead wire: $3 \mathrm{~m}$; error $\leq 1 \mathrm{~mm}$ ) were used to monitor the stresses and displacements of the rocks in the roof. Fig. 4 a shows the layout of the monitoring points. If the monitoring points were located in the immediate roof, they would have provided little data because the immediate roof tended to cave in soon after the underlying coal was excavated. For this reason, the monitoring points were laid out in a stable stratum (No. 10 stratum) above the roof, as shown in Fig. 10.
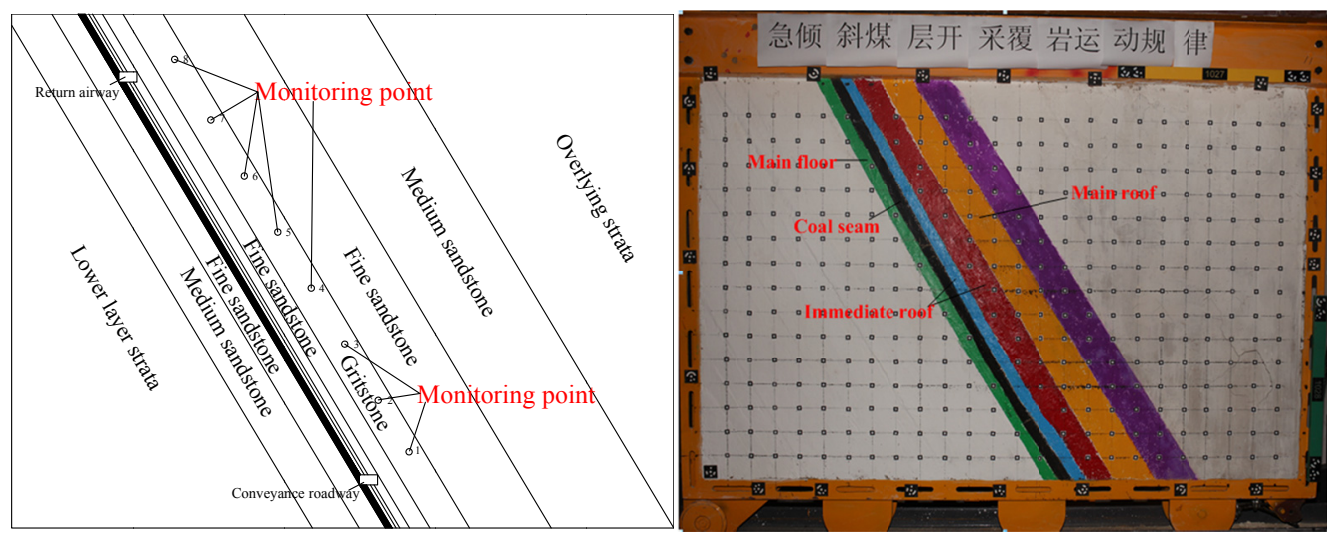

Fig. 4. Similar simulation experiment monitoring points layout

The mixing ratios of similar materials in each rock layer of the model are shown in Table 1. Three proportional parameters were used in this experiment: the mass ratio of sand to $\mathrm{CaCO}_{3}+$ gypsum, the mass ratio of $\mathrm{CaCO}_{3}$ to $\mathrm{CaCO}_{3}+$ gypsum, and the mass ratio of gypsum to $\mathrm{CaCO}_{3}+$ gypsum. Due to the large dip angle of the steep seam, the coal-cutting machine cut coal from the face only when it moved upward from the conveyance roadway to the ventilation roadway during actual mining. At the face, one cut lasted 40 minutes. Given the geometric similarity ratio of 1:100, the time similarity ratio was determined to be 1:10. Therefore, during the experimental mining, $2 \mathrm{~cm}$ thick coal was removed by each cut and the intervals between cuts were $6 \mathrm{~s}$. As this study focused on the characteristics of fracture and cave-in of the roof above the goaf, hydraulic supports independently developed by the laboratory (Fig. 5) were used as temporary supports in the experiment and then withdrawn from the bottom up after the coal was completely removed from the face. 
Material mass ratio of similar simulation

\begin{tabular}{|c|c|c|c|c|c|c|c|c|}
\hline \hline Nu. & $\begin{array}{c}\text { Lithological } \\
\text { characters }\end{array}$ & $\begin{array}{c}\text { Thickness } \\
(\mathbf{m})\end{array}$ & $\begin{array}{c}\text { Proportional } \\
\text { parameters }\end{array}$ & $\begin{array}{c}\text { Bulk density } \\
\left(\mathbf{k g} / \mathbf{m}^{\mathbf{3}} \mathbf{)}\right.\end{array}$ & $\begin{array}{c}\text { Sand } \\
\mathbf{( k g )}\end{array}$ & $\begin{array}{c}\text { CaCO} \\
\mathbf{( k g})\end{array}$ & $\begin{array}{c}\text { Gypsum } \\
(\mathbf{k g})\end{array}$ & $\begin{array}{c}\text { Water } \\
(\mathbf{k g})\end{array}$ \\
\hline 1 & Carbon mudstone & 29.3 & 773 & 25.52 & 40.11 & 4.01 & 1.72 & 6.55 \\
\hline 2 & Gritstone & 24.3 & 664 & 26.36 & 97.35 & 9.74 & 6.49 & 16.23 \\
\hline 3 & Mudstone & 18.1 & 791 & 25.30 & 107.84 & 13.86 & 1.54 & 17.61 \\
\hline 4 & Medium sandstone & 21.5 & 637 & 25.76 & 168.46 & 8.42 & 19.65 & 28.08 \\
\hline 5 & Fine sandstone & 26.7 & 737 & 25.48 & 255.21 & 10.94 & 25.52 & 41.67 \\
\hline 6 & Siltstone & 13.5 & 855 & 26.36 & 136.98 & 8.56 & 8.56 & 22.02 \\
\hline 7 & Gritstone & 6.4 & 546 & 26.78 & 61.85 & 4.95 & 7.42 & 10.60 \\
\hline 8 & Mudstone & 11.7 & 864 & 25.30 & 113.93 & 8.55 & 5.70 & 18.31 \\
\hline 9 & Medium sandstone & 12.6 & 655 & 26.14 & 122.25 & 10.19 & 10.19 & 20.38 \\
\hline 10 & Fine sandstone & 14.3 & 737 & 26.39 & 142.96 & 6.13 & 14.30 & 23.34 \\
\hline 11 & Gritstone & 5.1 & 673 & 26.54 & 50.25 & 5.86 & 2.51 & 8.37 \\
\hline 12 & Fine sandstone & 1.3 & 346 & 25.76 & 10.87 & 1.45 & 2.17 & 2.07 \\
\hline 13 & Siltstone & 1.1 & 646 & 25.64 & 10.47 & 0.70 & 1.05 & 1.74 \\
\hline 14 & Mudstone & 0.9 & 782 & 13.65 & 4.66 & 0.53 & 0.13 & 0.76 \\
\hline 15 & Siltstone & 1 & 346 & 24.41 & 7.93 & 1.06 & 1.59 & 1.51 \\
\hline 16 & $49^{\#}$ lower steep seam & 2 & 837 & 3.41 & 10.51 & 0.39 & 0.92 & 1.69 \\
\hline 17 & Siltstone & 10 & 873 & 40.55 & 101.45 & 8.88 & 3.80 & 16.30 \\
\hline 18 & Medium sandstone & 13.6 & 637 & 25.43 & 128.37 & 6.42 & 14.98 & 21.40 \\
\hline 19 & Gritstone & 10.4 & 673 & 24.77 & 91.64 & 10.69 & 4.58 & 15.27 \\
\hline 20 & Carbon mudstone & 16.1 & 746 & 25.23 & 127.20 & 7.27 & 10.90 & 20.77 \\
\hline 21 & Fine sandstone & 19.2 & 346 & 26.17 & 106.06 & 14.14 & 21.21 & 20.20 \\
\hline 22 & Medium sandstone & 16.3 & 346 & 26.10 & 65.29 & 8.71 & 13.06 & 12.44 \\
\hline 23 & Siltstone & 18.6 & 646 & 24.43 & 50.26 & 3.35 & 5.03 & 8.38 \\
\hline 24 & Mudstone & 20.5 & 582 & 25.30 & 19.17 & 3.07 & 0.77 & 3.29 \\
\hline & & & & & & & & \\
\hline
\end{tabular}

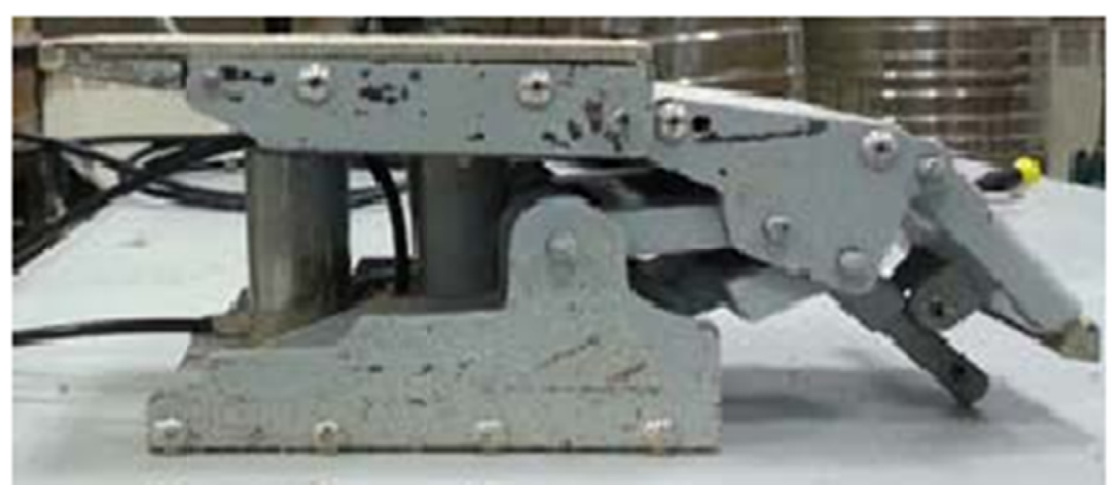

Fig. 5. Hydraulic support used in the experiment 


\section{Results}

\subsection{Characteristics of the fracture of the immediate roof}

It has been statistically established that the caving gangue from the roof is able to slip down when $\tan \alpha>f$, where $f$ is the coefficient of friction between the gangue and the floor of the goaf, and $\alpha$ is the seam's dip angle. Normally, the coefficient of friction is $f=0.6 \sim 0.7$, which means that the slip of gangue can occur when the dip angle satisfies $\alpha>31 \sim 35^{\circ}$. Moreover, the gangue tends to slip more violently with larger $\alpha$.

The immediate roof of the working face was thin and composed of fine sandstone and coal seam, as shown in the stratigraphic column of the coal seam. Since the longwall mining equipment moved upward along the face, the fracture and cave-in of immediate roof first occurred in the lower part of the working face (Fig. 6a). Due to the large dip angle, the fractured immediate roof in the middle and upper regions fell upon the goaf and occupied its lower space (Fig. 6b), preventing further deformation of the lower roof. Observing the lithologic properties of the overlying strata and the mechanical behavior, it was found that the immediate roof below the main roof consisted of two types of rock strata: immediate caving rock strata and hysteretic caving rock strata. The immediate caving rock strata were the strata that caved in immediately after the face supports under them were moved away. The suspended segments of these strata were shorter than the width of a single support, which is $1.5 \mathrm{~m}$. In comparison, the lengths of the hysteretic caving rock strata's suspended segments were usually 2 to 5 times the width of a support (Qian \& Shi, 2003). The immediate caving rock strata that were no longer supported by coal could fall soon after the longwall mining equipment was withdrawn. Thus it was assumed that the caving of immediate caving rock strata progressed with the working face. Supported by the gangue from the fallen immediate caving rock strata, the hysteretic caving rock strata in the lower region of the working face were protected from deforming and collapsing. Therefore the cave-in of hysteretic caving rock strata mainly occurred in the upper working face and alternated with

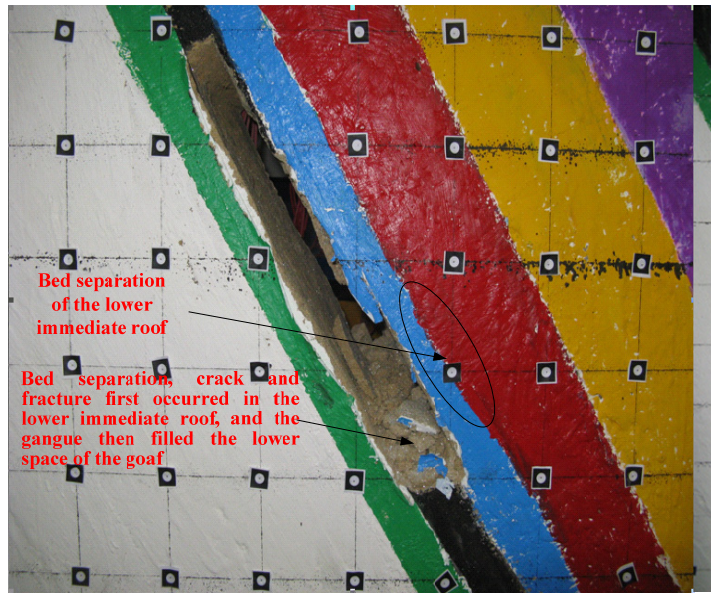

a

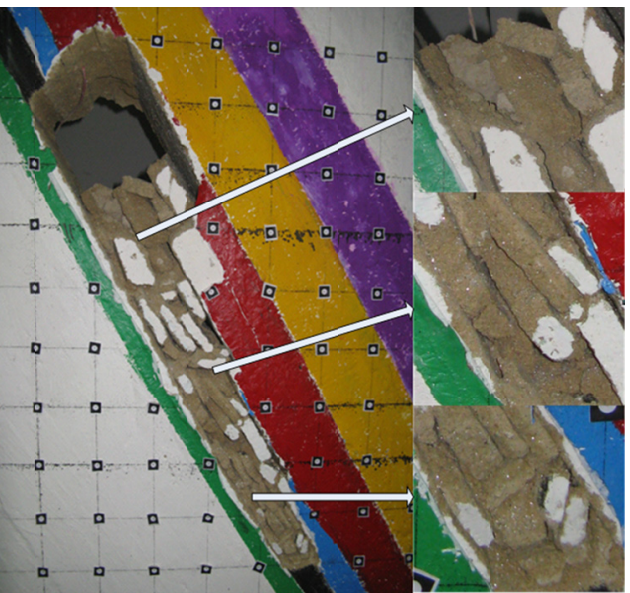

b

Fig. 6. Immediate roof separation and caving characteristics of lower part face in steeply inclined coal face 
the slip of the gangue periodically as mining progressed. In the upper part of the working face, the roof was not supported by the gangue and experienced more violent fracturing and collapse. Therefore, it was concluded that the roof upward along the goaf was increasingly destabilized and thus experienced more intense collapse as the steep working face advanced.

\subsection{Characteristics of the fracture of the main roof}

According to the characteristics of the immediate roof caving and gangue backfill, the main roof of the steep coal face was supported by the gangue from the lower roof and the coal pillars around. The deformation and fracture of the main roof mainly occurred in the middle and upper parts of the working face. As the working face advanced, expanding area of the main roof was hanging above the goaf, which required a larger load from the roof supports to keep the main roof and overlying strata stable. Therefore, the gangue backfill in the goaf, whose degree of compression and load capacity gradually reduced with height, would be destabilized when the load applied to the roof exceeded its load capacity. As a result, the supporting point for the unstable suspended roof tended to move downward to the lower goaf, and the distance between the main roof and the conveyance roadway gradually increased. When the distance reached a certain limit, the main roof would break into rock masses. In the experiment, the broken main roof then formed a sloping "voussoir beam" structure, as shown in Fig. 7. (A three-dimensional numerical simulation study has indirectly confirmed that the broken roof can form such structure along the dip direction of the face and does not form any structure along the direction of advance of the face ( $\mathrm{Tu}, 2014)$ ).

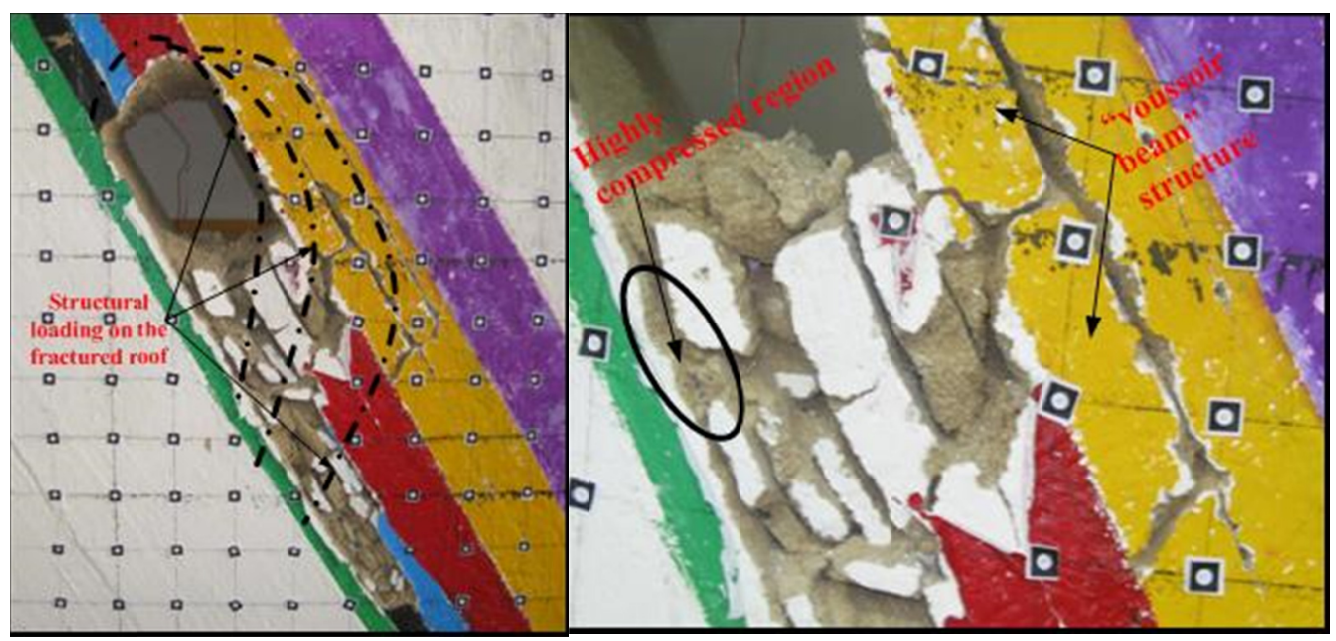

Fig. 7. Sloping "voussoir beam" structure of main roof

Fig. 8 demonstrates the roof's stress and displacement variations in the dip direction of the working face during the experiment.

Fig. 8 implies that, before mining, there was a linear relationship between the stress in the main roof and its distance from the conveyance roadway. After the mining began, the main roof in the lower part of the working face, which was supported by the gangue and the immediate 


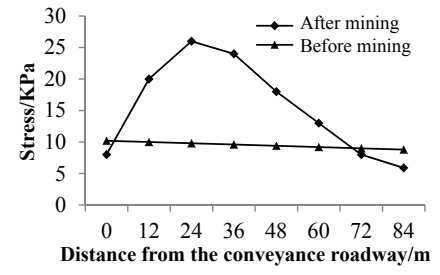

(a) Stress variations

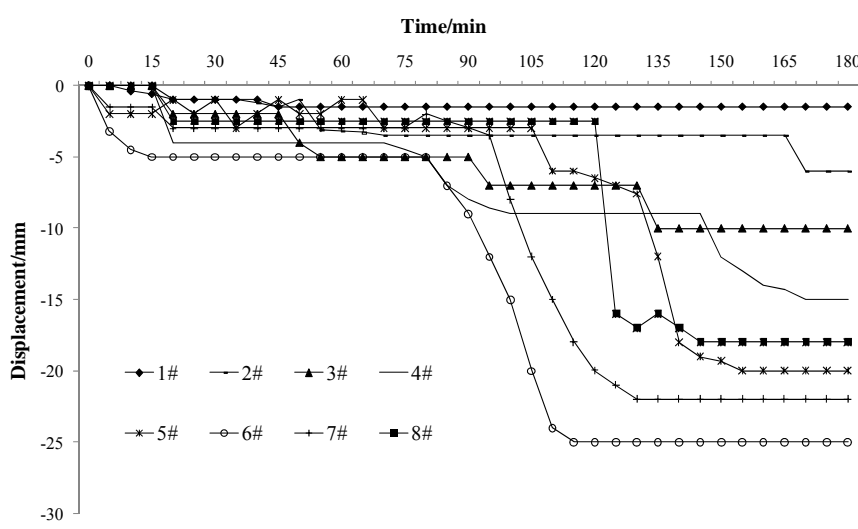

(b) Displacement variations

Fig. 8. Stress and deformation law of main roof

roof, underwent weak bed separation and large stress, and thus had high stability. Since the lower immediate roof was supported mainly by the gangue and imposed small forces on the support, the hydraulic roof supports in this region would be loaded with relatively small forces during a real mining process. By contrast, the main roof in the middle and upper parts of the working face was subjected to severe deformation and small stress and thus was less stable. As the roof in this region was mostly suspended and exerted large forces on the support, the corresponding hydraulic roof supports would be loaded with relatively large forces during a real mining process. The maximum displacement of the roof occurred at the location about $70 \mathrm{~m}$ from the lower end of the working face.

\section{Characteristics of the backfill of caved immediate roof and the stability of main roof}

\subsection{Width of backfill in the goaf}

The region backfilled with caved immediate roof in the goaf was delineated according to the characteristics of the caving and movement of immediate roof, as shown in Fig. 9.

The polygon GDEF' in Fig. 10 defines the region backfilled with gangue in the goaf during actual mining. EF is significantly longer than FF' at an actual face (EF and FF' have similar lengths in this schematic diagram because the schematic diagram shown in this figure was not drawn to scale). Additionally, the ratio of FF' length to EF' length tends to decrease with increasing dip angle of the seam in real mining. Therefore, this ratio for a steeply dipping seam is often negligible. Moreover, using a schematic diagram that is accurate to scale will make it very difficult to derive an analytical expression for the width of backfill in the goaf (Tu, 2014). In order to facilitate analysis, therefore, the caving region in the middle and upper parts of the working face was simplified to a trapezoid region, as shown in Fig. 10. 


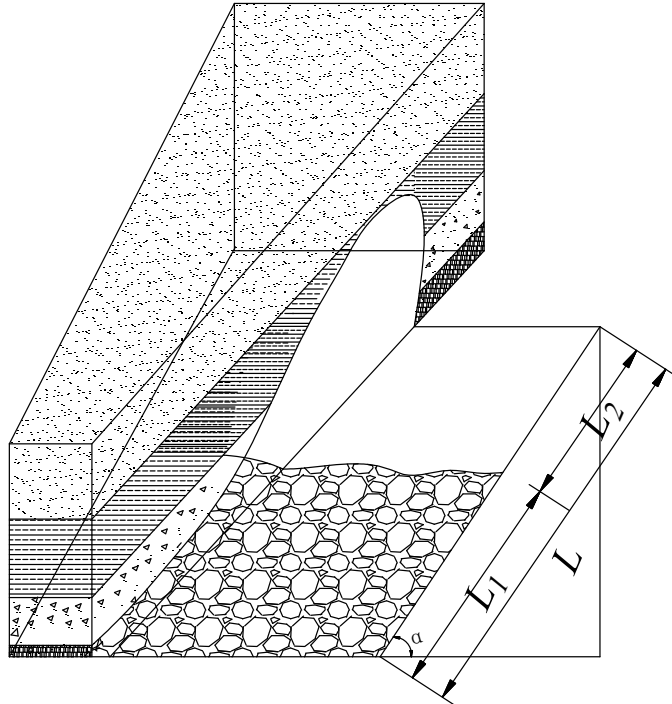

(a) Stereogram

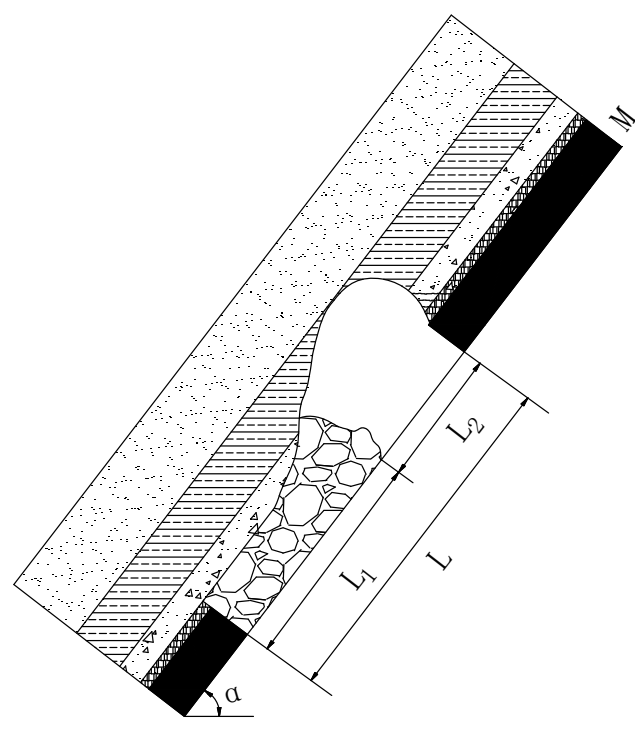

(b) Cross-section drawn

Fig. 9. Schematic diagram of gangue caving and filling in goaf

$M$ - the mining height of the working face; $L$ - the length of the working face; $L_{l}$ - the width of backfill in the goaf's lower part

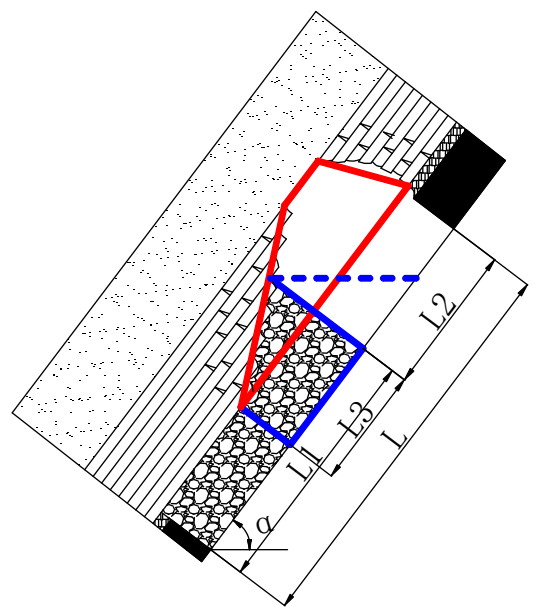

(a) Sketch drawn

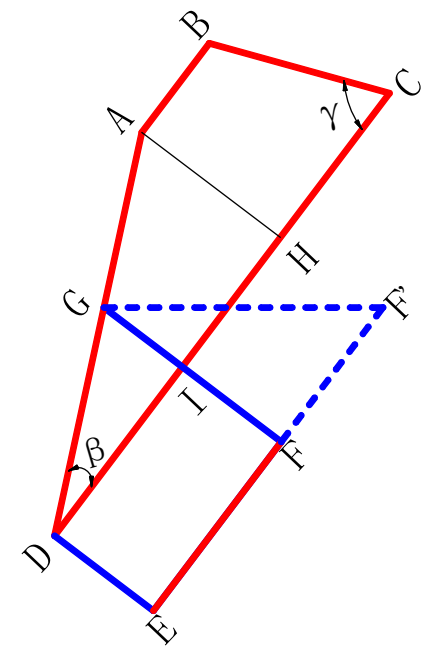

(b) Geometrical relationship

Fig.10. Sketch of caving characteristic in goaf

$L_{3}$ - the width of the region filled with the gangue from the hysteretic caving rock strata; $\beta$ - the lower caving angle of the working face; $\gamma$ - the upper caving angle of the working face 
According to Fig. 10b, the width of the region occupied by the gangue from the hysteretic caving rock strata was determined by the length of DI or EF, and the thickness of hysteretic caving rock strata, $\mathrm{H}_{2}$, was represented by the length of $\mathrm{AH}$. The length of $\mathrm{AB}$ was given by:

$$
A B=L_{2}+L_{3}-\frac{H_{2}}{\tan \beta}-\frac{H_{2}}{\tan \gamma}
$$

Then, the lengths of CD, DE, and GF can be calculated using Formula (1) in combination with their geometric relationships:

$$
\left\{\begin{array}{l}
C D=L_{2}+L_{3} \\
D E=H_{1}+M \\
G F=L_{3} \tan \beta+H_{1}+M
\end{array}\right.
$$

Moreover, the relationships between $L_{1}, L_{2}$, and $L_{3}$ were given by:

$$
\left\{\begin{array}{l}
L_{1}=\frac{L H_{1} k}{H_{1}+M}+L_{3} \\
L_{2}=L-\frac{L H_{1} k}{H_{1}+M}-L_{3}
\end{array}\right.
$$

According to the geometric shapes in Fig. 10b, the volume of rocks within the trapezoid $\mathrm{ABCD}$ after dilatation equaled the volume of the trapezoid DEFG. Combining this with Formulas (1) (3), the formula describing the width of the backfill in the goaf's lower region was yielded:

$$
L_{1}=\frac{1}{\tan \beta+2 H_{1}+2 M}\left[2 L H_{2} k-\frac{2 L H_{1} H_{2} k}{\left(H_{1}+M\right)}-H_{2}{ }^{2} k\left(\frac{1}{\tan \beta}-\frac{1}{\tan \gamma}\right)\right]
$$

Where $k$ is the dilatation coefficient of the caved rock masses, generally between 1.25 and 1.5. In the Xintie Coal Mine, the working face of the steep seam was $84 \mathrm{~m}$ and the mining height was $1.7 \mathrm{~m}$. The lower and the upper caving angles of the working face were $30^{\circ}$ and $61^{\circ}$ respectively. To analyze the influences of different mining parameters on the width of backfill in the goaf, the following curves were plotted to illustrate the relationships between the width of backfill and the parameters.

As shown in Fig. 11, the width of backfill increased linearly with the thickness and dilatation coefficient of hysteretic caving rock strata and with the length of working face. When the mining height was less than $1 \mathrm{~m}$, the width of backfill in the lower goaf increased sharply with mining height. When the mining height exceeded $1 \mathrm{~m}$, the width of backfill in the lower goaf reduced slowly with mining height. Given that the coal thickness is normally larger than $1 \mathrm{~m}$ in steep fully-mechanized working faces, it was concluded that the width of backfill decreased with mining height, while it increased with the thickness and dilatation coefficient of hysteretic caving rock strata and the length of working face. 

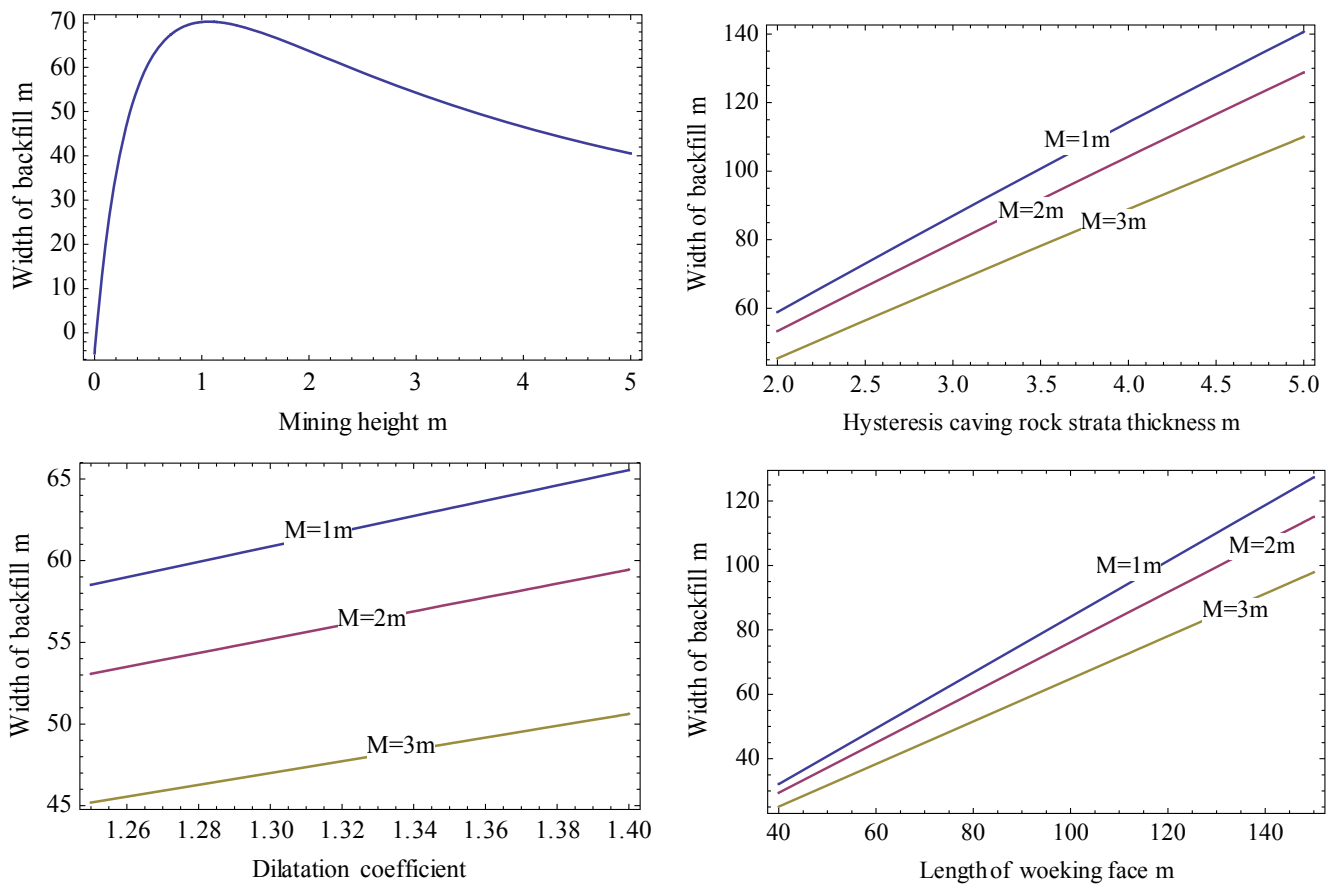

Fig. 11. Variation law of backfilling region width in goaf

\subsection{Stability of the "Voussoir Beam" structure}

The broken main roof tended to sink and rotate, generating a great compressive stress between the adjacent rock masses. When the compressive stress was smaller than the compressive strength of the rock strata, the rock masses would form a temporarily balanced "voussoir beam" structure (Fig. 12), which can act as a support for the overlying strata and thus help maintain a safe working place along the working face.

The formation of the sloping "voussoir beam" structure was controlled by the compressive stress, friction, and shear stress on the occlusion face between adjacent rock masses, and the rock's compressive strength. When the compressive stress exceeded the compressive strength, the rock masses tended to keep rotating and deforming, leading to deformationinduced instability. When the shear stress was larger than the friction, the rock masses kept sinking, giving rise to slip-induced instability. The stress state of the rock masses of broken main roof was simplified, as shown in Fig. 13.

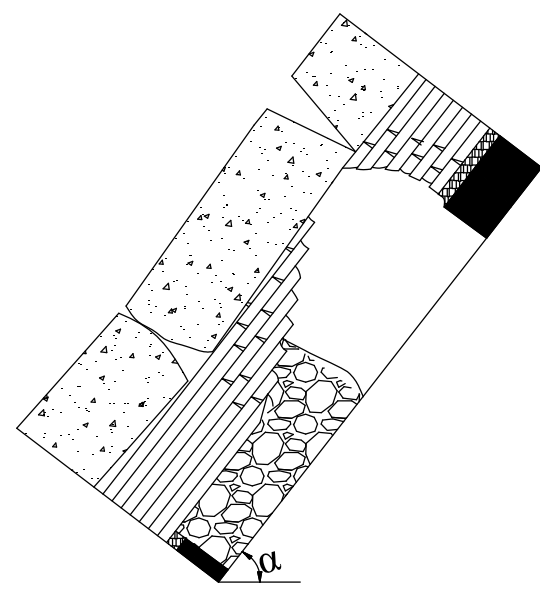

Fig. 12. Sloping voussoir beam structure of broken main roof 

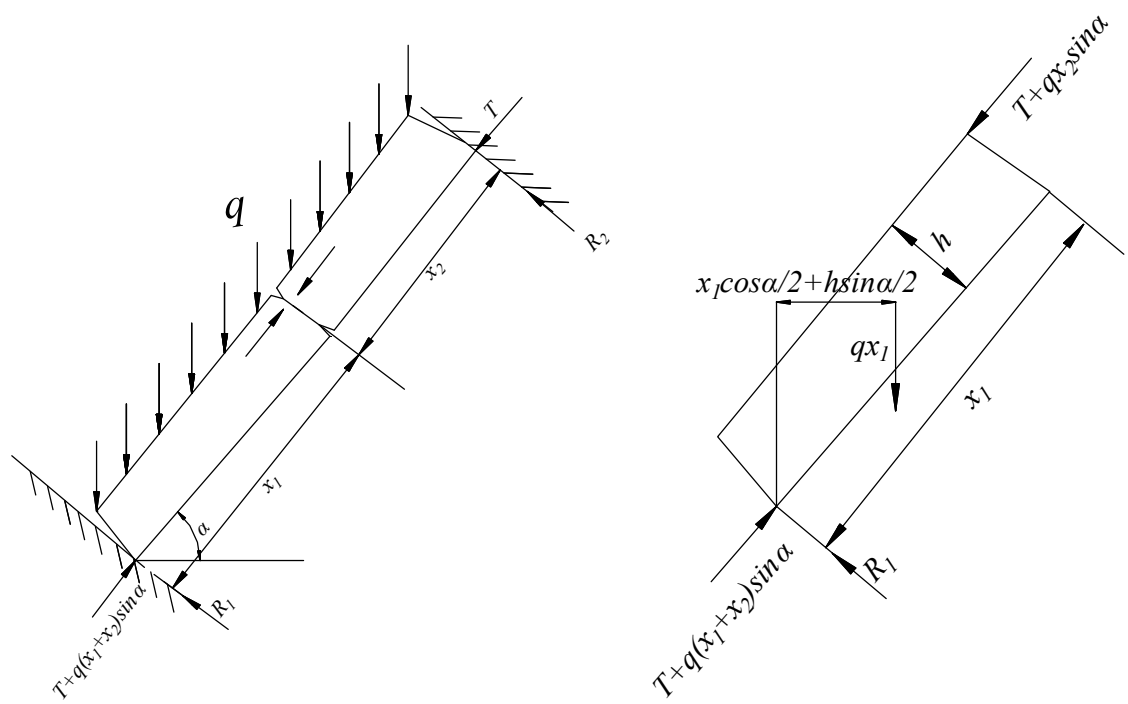

Fig. 13. Stress analysis of sloping voussoir beam structure

The presence of compressive stress parallel to strata is a precondition for the formation of roof structures. Previous stability analyses of roof structure focused on roofs above horizontal coal seams. The compressive stress parallel to strata experienced by a horizontal roof mainly results from the rotation of roof. For a steeply dipping roof, the compression is composed of two components: the compressive stress arising from the roof rotation and the component of the force of gravity parallel to the strata. Therefore, the characteristics of the model were analyzed based on the stress state of the roof above a steeply dipping seam described above.

The analysis demonstrated that the voussoir beam structure can be destabilized by two instability factors: deformation-induced instability and slip-induced instability. The stability analysis required different methods specific to the two factors, as they could cause different forms of motion of the structure. This subsection will use the theory of elasticity to determine the criteria for identifying the two instability factors.

\section{1) Slip-induced instability}

The friction on the occlusion face between adjacent rock masses was obtained by multiplying the normal stress by the friction coefficient, the direction of friction was opposite the trend of each rock mass. For example, the rock in Fig. 13 has a tendency to slip down. The equilibrium equations for the structure were built according to the theory of static equilibrium:

$$
\left\{\begin{array}{l}
R_{1}+R_{2}=q\left(x_{1}+x_{2}\right) \cos \alpha \\
q x_{1}\left(\frac{x_{1}}{2}-\frac{h \tan \alpha}{2}\right) \cos \alpha=\left(T+q x_{2} \sin \alpha\right) h \\
q\left(x_{1}+x_{2}\right)\left(\frac{x_{1}+x_{2}}{2}-\frac{h \tan \alpha}{2}\right) \cos \alpha=R_{2}\left(x_{1}+x_{2}\right)
\end{array}\right.
$$


Formula (5) must satisfy the boundary condition that the compressive stress on an arbitrary fracture surface must be smaller than its compressive strength $\left[\sigma_{c}\right]$, i.e.

$$
\left\{\begin{array}{l}
h>0, x>0 \\
\frac{q \sum_{i=1}^{n} x_{i}+T}{h}<\left[\sigma_{\mathrm{c}}\right]
\end{array}\right.
$$

The following functions can be obtained by solving the equations above:

$$
\left\{\begin{array}{l}
R_{1}=\frac{x_{1}+x_{2}}{2} q \cos \alpha+\frac{h}{2} q \sin \alpha \\
R_{2}=\frac{x_{1}+x_{2}}{2} q \cos \alpha-\frac{h}{2} q \sin \alpha \\
T=\frac{q x_{1}^{2} \cos \alpha}{2 h}-\frac{q x_{1} \sin \alpha}{2}-q x_{2} \sin \alpha
\end{array}\right.
$$

Where $R_{1}$ and $R_{2}$ are the frictions on the occlusion faces; $q$ is the force on the main roof applied by overlying strata; $x_{1}$ and $x_{2}$ are the lengths of the rock masses; $h$ is the thickness of the main roof; and $T$ is the compressive stress parallel of adjacent rock masses. According to the stress state of the structure, the lowest occlusion face should be subjected to the largest shear stress. Therefore, the rock masses can be prevented from slipping if the compressive stress and friction satisfy:

$$
\left[T+q\left(x_{1}+x_{2}\right) \sin \alpha\right] \tan \varphi \geq R_{1}
$$

Synthesizing Formula (7) and Formula (8) can yield the condition for maintaining the structure's stability:

$$
\tan \varphi \geq \frac{h\left(x_{1}+x_{2}\right) \cos \alpha+h^{2} \sin \alpha}{x_{1}^{2} \cos \alpha+h x_{1} \sin \alpha}
$$

where $\varphi$ is the angle of friction between adjacent rock masses. If the lengths of the two rock masses are equal, i.e. $x_{1}=x_{2}$, the formula above can be rearranged as follows:

$$
\tan \varphi \geq \frac{2 h x \cos \alpha+h^{2} \sin \alpha}{x^{2} \cos \alpha+h x \sin \alpha}=\frac{h}{x}+\frac{1}{\frac{1}{\left(\frac{h}{x}\right)}+\tan \alpha}
$$

where $h / x$ is the width to length ratio of the "voussoir beam" structure. The formula above implies that the width to length ratio, $h / x$, and the strata's dip angle, $\alpha$, are the main factors that influence the occurrence of slip of the rock masses: the structure's anti-slip capacity declines with $h / x$ and grows with $\alpha$. Therefore, the rock masses of broken main roof above a steep coal seam have a greater anti-slip capacity than those above a horizontal coal seam, and thus are more likely to form the "voussoir beam" structure and less susceptible to slip-induced instability. 
The angle of friction between adjacent rock masses is typically in the range of $38 \sim 45^{\circ}$ ( $\tan \varphi=0.8 \sim 1$ ), But for the steep seam dipping $60^{\circ}$ in the Xintie Coal Mine, $h / x$ should be smaller than $0.5 \sim 0.7$ in order to prevent the "voussoir beam" structure from slipping, which means that the length of each rock mass should be larger than $1.4 \sim 2$ times its width.

\section{2) Deformation-induced instability}

When the compressive stress between adjacent rock masses caused by rotation and deformation exceeded the compressive strength of the rock masses, plastic deformation occurred in the region around the occlusion face, intensifying the fracture, rotation and deformation of the rock masses. When the amount of deformation reached a certain value, the structure was destabilized. Fig. 14 displays the deflection distance and deflection angle of a rock mass when the deformation-induced instability of the "voussoir beam" structure arises.

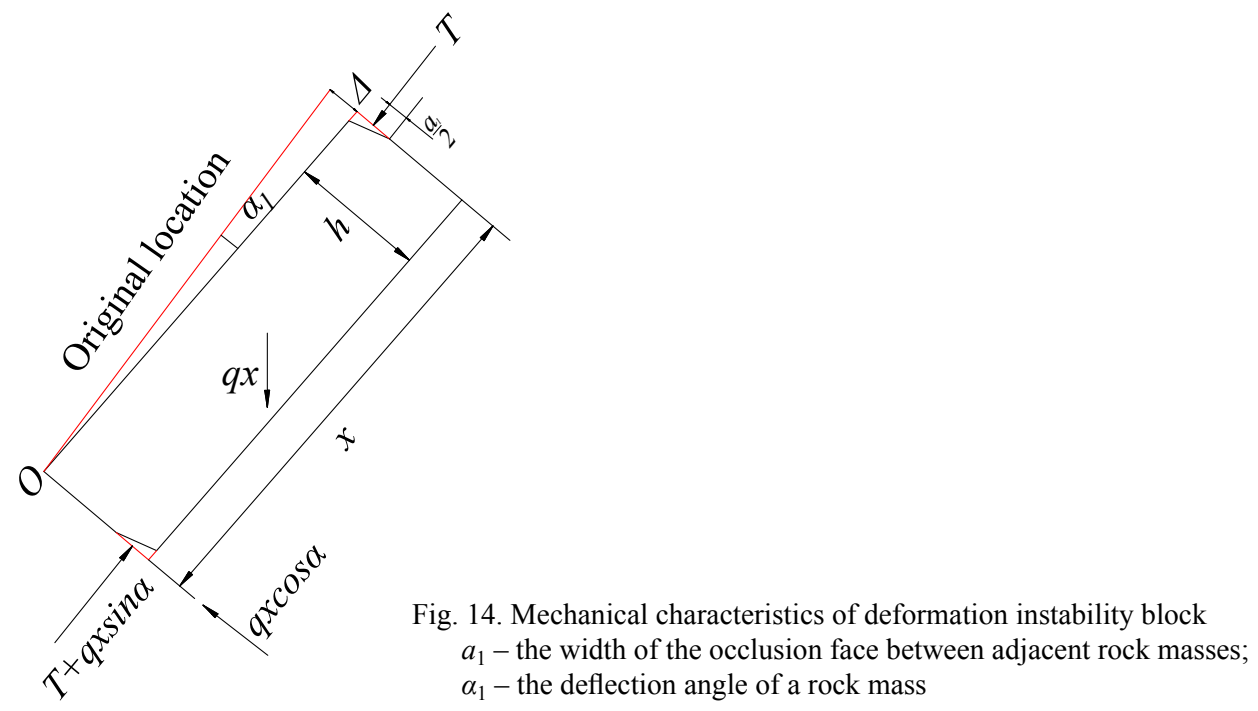

For a rotating rock mass to be in equilibrium, the sum of the moments about any point must be zero, that is, $\sum M=0$. Thus, to keep the rock mass in Fig. 14 in equilibrium, the moments around the point $O$ should satisfy:

$$
T\left(h-a_{1}-\Delta\right)=\frac{x \cos \alpha-h \sin \alpha+a \sin \alpha}{2} q x
$$

The formula above must satisfy the boundary condition that the compressive stress on an arbitrary fracture surface must be greater than its compressive strength $\left[\sigma_{c}\right]$, i.e.

$$
\left\{\begin{array}{l}
h>0, x>0 \\
\frac{q \sum_{i=1}^{n} x_{i}+T}{h}>\left[\sigma_{\mathrm{c}}\right]
\end{array}\right.
$$


When $a_{1}$ is small, it can be described by:

$$
\left\{\begin{array}{l}
a_{1}=\frac{h-x \sin \alpha_{1}}{2} \\
\Delta=x \sin \alpha_{1}
\end{array}\right.
$$

Combining Formula (13) with Formula (11) can yield the formula below:

$$
T=\frac{2 x \cos \alpha-h \sin \alpha-x \sin \alpha \sin \alpha_{1}}{2\left(h-x \sin \alpha_{1}\right)} q x
$$

Therefore, the compressive stress exerted on the point $O$ can be expressed by:

$$
\sigma_{p}=\frac{T}{a_{1}}=\frac{2 x \cos \alpha-h \sin \alpha-x \sin \alpha \sin \alpha_{1}}{\left(h-x \sin \alpha_{1}\right)^{2}} q x
$$

The ratio of the compressive stress, $\sigma_{p}$, to the compressive strength of the rock mass, $\left[\sigma_{c}\right]$, was denoted $\bar{K}$. Then the maximum load exerted on the rock mass by overlying strata can be expressed by:

$$
q=\frac{\bar{K}\left[\sigma_{c}\right]\left(h-x \sin \alpha_{1}\right)^{2}}{\left(2 x \cos \alpha-h \sin \alpha-x \sin \alpha \sin \alpha_{1}\right) x}
$$

In the light of the relationship between the maximum load and the rock mass's tensile strength, the maximum load on the rock mass can be given by:

$$
q=\frac{\left[\sigma_{t}\right]}{6 K\left(\frac{x}{h}\right)^{2}}
$$

The value of $K$, normally in the range of $1 / 3 \sim 1 / 2$, is determined by the boundary conditions of the rock mass. Combining Formulas (16) and (17) can yield the following functions:

$$
\left\{\begin{array}{l}
\sin \alpha_{1}=\frac{h}{x}\left[1-\sqrt{\frac{\left[\sigma_{t}\right]}{6 K \bar{K}\left[\sigma_{c}\right]}\left(2 \cos \alpha-\frac{h}{x} \sin \alpha\right)}\right] \\
\Delta=h\left[1-\sqrt{\frac{\left[\sigma_{t}\right]}{6 K \bar{K}\left[\sigma_{c}\right]}\left(2 \cos \alpha-\frac{h}{x} \sin \alpha\right)}\right]
\end{array}\right.
$$

The deflection at the occlusion face of the rock masses can be calculated using Formula (18). When the real deflection distance is larger than the value of $\Delta$ calculated from the formula, deformation-induced instability will arise. As the dip angle increases, the rock masses of broken main roof will experience greater deflection, and thus are more susceptible to deformation-induced instability. Moreover, the rock masses having greater compressive strength are more stable.

The stability analysis above indicated that, as the seam's dip angle increased, the rock masses of fractured roof had greater capacity to withstand slip-induced instability but smaller capacity 
to withstand deformation-induced instability. This indicates that the main roof of a steep coal face is normally susceptible to deformation-induced instability.

\section{Mine pressure in the working face}

To study the variation in the forces exerted on the hydraulic supports during mining, a number of observation points were arranged in different locations (the upper, middle, and lower parts) in the working face. Fig. 15 shows the layout of monitoring points throughout the working face.

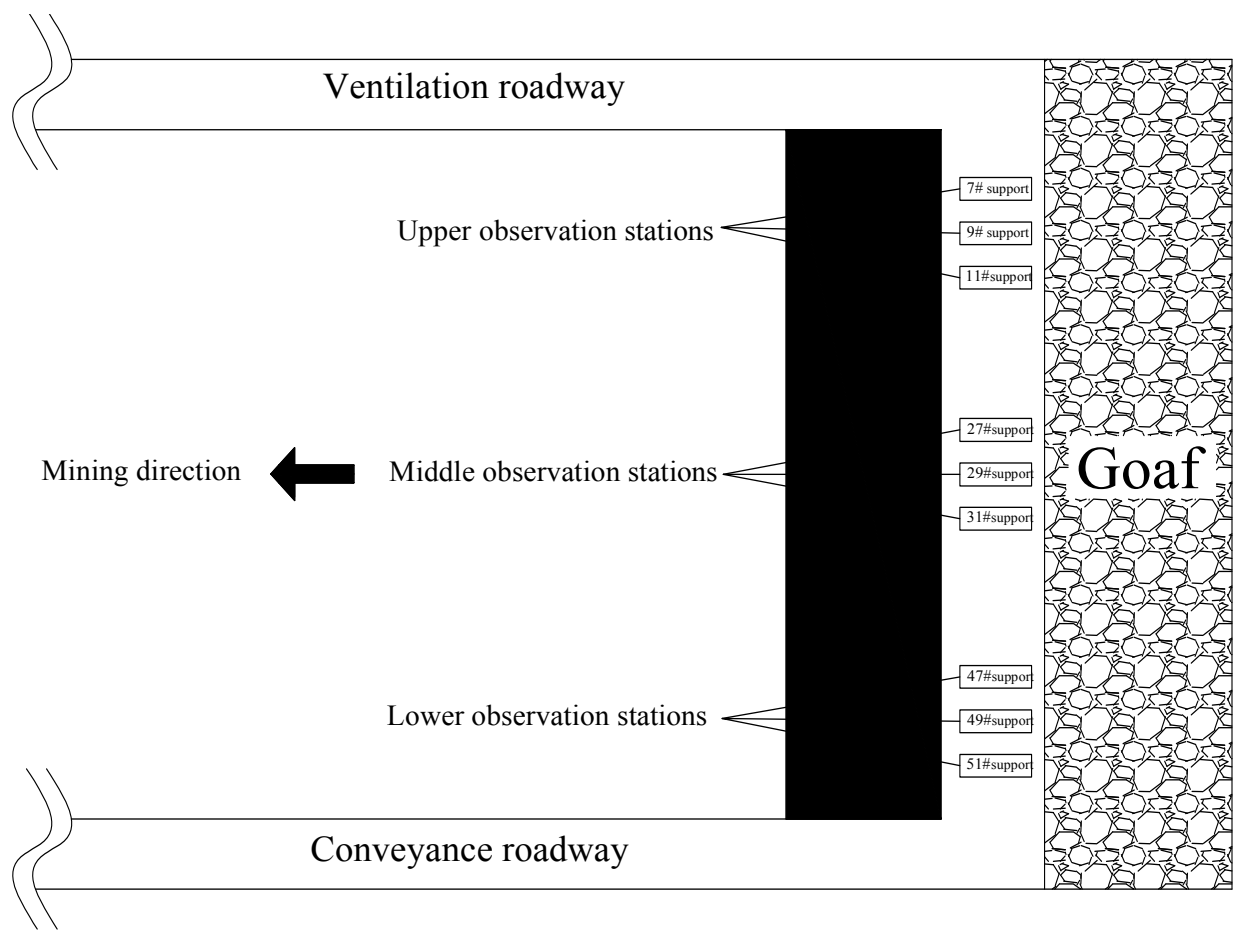

Fig. 15. Layout of monitoring points throughout the working face

Fig. 16 displays the variations in the forces exerted on the hydraulic supports in different locations during a mining process until the working face advanced $102 \mathrm{~m}$.

The curves above showed a visible asynchrony in the characteristics of roof weighting in different parts of the steep working face. The hydraulic supports in the upper part were subjected to the largest forces, and the force increases caused by roof weighting were the sharpest. But the roof weighting step in the upper part was the smallest. Therefore, maintaining the stability of the hydraulic supports in this region is a key task in surrounding rock management. The hydraulic supports in the lower part were subjected to smallest forces, and the resulting force increases were the smallest. Roof weighting step in this region was the largest.

Fig. 17 illustrates the forces exerted on the hydraulic supports in the dip direction. 


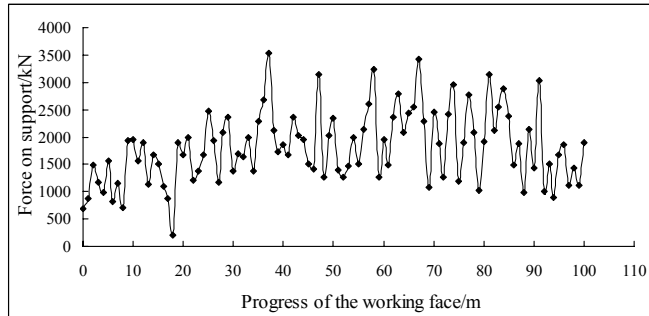

(a) Upper

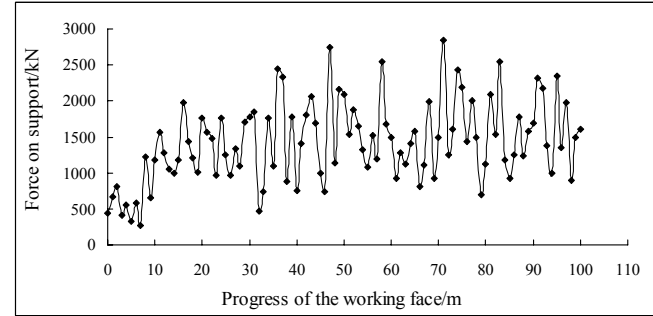

(b) Middle

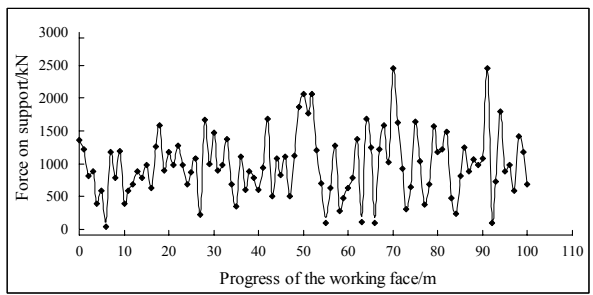

(c) Lower

Fig. 16. The forces exerted on the hydraulic supports

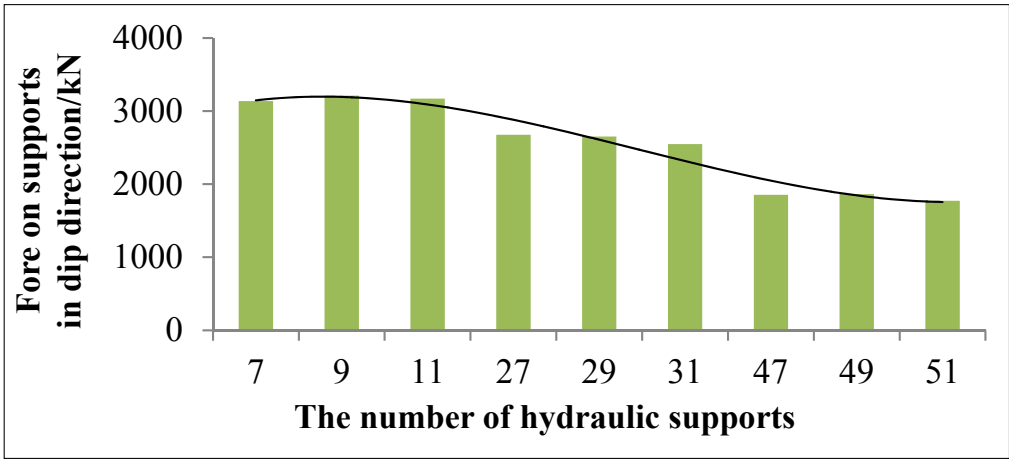

Fig. 17. The forces exerted on the hydraulic supports in dip direction

As shown in the figure above, the forces exerted on the hydraulic supports in the upper part ranged from 3100 to $3200 \mathrm{kN}$, compared to the $2500-2700 \mathrm{kN}$ on the middle supports and the $1700-1900 \mathrm{kN}$ on the lower supports. These forces were much smaller than the forces of about $5800 \mathrm{kN}$ on the hydraulic supports in a nearly horizontal seam at the same depth, which were calculated using an empirical formula for calculating support resistance (Zhang et al., 2013). This is due to the presence of a voussoir beam structure formed from fractured roof in the dip direction. The forces on the lower supports were smaller than those on the middle and upper supports because the goaf-filling caved gangue provided support for the roof in the lower part of the face. Moreover, the gangue was compacted more tightly in the lower part than in the middle part. These findings indirectly verify the characteristics of gangue backfill and the existence of an along-dip voussoir beam structure at the working face of a steeply dipping seam. 


\section{Conclusions}

(1) Based on the geological conditions of a steep coal seam in the Xintie Coal Mine, a similar simulation experiment was carried out to study the structural features of the mine roof during mining. It was found that the immediate roof of the steep working face tended to collapse upon the goaf and backfill its lower space. As a result, the roof in the lower part of the working face had higher stability than the roof in the upper part.

(2) Deformation and fracture of the main roof mainly occurred in the upper part of the working face. The fractured main roof then formed a "voussoir beam" structure in the strata's dip direction.

(3) A method of calculating the width of gangue backfill in the goaf was developed according to the characteristics of the caving of the immediate roof and gangue backfill. An analysis was performed to investigate the influences of different mining parameters (including the thickness of the hysteretic caving rock strata, rock's dilatation coefficient, length of working face and mining height) on the width of backfill in the goaf.

(4) The stability analysis revealed that the main roof's structure was subjected to slip- and deformation-induced instability. The conditions for maintaining the stability of the main roof specific to the two instability factors were obtained using the methods in rock mechanics. It was found that, when the dip angle increased, the rock masses had greater capacity to withstand slip-induced instability but smaller capacity to withstand deformation-induced instability. This indicates that the main roof of a steep coal face is normally susceptible to deformation-induced instability

(5) The hydraulic supports in the upper part were subjected to the largest forces, and the force increases caused by roof weighting were the sharpest. However, the roof weighting step in the upper part was the smallest. The hydraulic supports in the lower part were subjected to smallest forces, and the resulting force increases were the smallest. These results demonstrated the validity of the characteristics of roof caving and gangue backfill during the mining of a steep seam discovered in the simulation experiment.

\section{Acknowledgement}

Financial support for the Fundamental Research Funds for the Central Universities (No. 2015QNB11), the Priority Academic Program Development of Jiangsu Higher Education Institutions. The authors gratefully acknowledge financial support of the above items.

\section{References}

Bodi J., 1997. Safety and technological aspects of manless exploitation technology for steep coal seams [A]. 27th International Conference of Safety in Mines Research Institutes [C], 955-965.

Deb D., Choon Sunwoo, Jung Yong-bok., 2009. Pit optimization for steep coal seams at Pasir coal mine, Indonesia [J]. Journal of the Korean Society of Mineral and Energy Resources Engineers, 46 (5), 509-520.

Gao Ming-zhong., 2004. Similarity model test of strata movement with steep seam [J]. Chinese Journal of Rock Mechanics and Engineering 23 (3), 441-445 (in Chinese). 
Ju Wen-jun, Li Wen-zhou, 2008. Fracture mechanical model of main roof along inclined for fully-mechanized top coal caving in steep and extra-thick coal seam [J]. Journal of China Coal Society 33 (6), 606-608, (in Chinese).

Kulakov V N., 1995. Stress state in the face region of a steep coal bed [J]. Journal of Mining Science, (9), 161-168. (Russian Federation).

Li Dong., 2010. Damage rule of surrounding rock in critical angle steep coal seam [J]. Coal Engineering, (1), 54-55 (in Chinese).

Li Xiao-meng, Liu Fei., 2016. Analysis of overlying strata structure and strata behavior characteristics of stope in steep coal seam [J]. Coal Engineering, 48 (5), 80-83 (in Chinese).

Liu Chang-you, Yang Jing-xuan, Wu Feng-feng., 2015. A proposed method of coal pillar design, goaf filling, and grouting of steeply inclined coal seams under water-filled strata [J]. Mine Water and the Environment, 34 (1), 87-94.

Luo Sheng-hu, Wu Yong-ping, Liu Kong-zhi, Xie Pan-shi, Lang-ding. 2016. Study on the shape of the space stress arch shell in steeply dipping coal seam mining [J]. Journal of China Coal Society 41 (12), 2993-2998 (in Chinese).

Niu Hui-yong, Qiao Chen-lu, An Jing-yu, Deng Jun., 2015. Experimental study and numerical simulation of spread law for fire on tunnel [J]. Journal of Central South University, 22 (2), 701-706.

Qian Ming-gao, Shi Ping-wu., 2003. Underground pressure and strata control [M]. Xuzhou: China University of Mining and Technology Press,

Ren Fen-hua, Lai Xing-ping, Cai Mei-feng., 2008. Dynamic destabilization analysis based on AE experiment of deep-seated, steep-inclined and extra-thick coal seam [J]. Journal of University of Science and Technology Beijing, 15 (3), 215-219.

Tu Hong-sheng., 2014. Overlying strata movement law and control mechanism of fully mechanised longwall mining face in thin and medium thickness steeply inclined coal seam [D]. Xuzhou: Master Dissertation of China University of Mining and Technology.

Wang Ming-li., 2009. Research on damage mechanism of floor rock in mining steeply inclined coal seam [J]. Coal mining technology 14 (3), 87-89 (in Chinese).

Wu Ai-xiang, Huang Ming-qing, Han Bin, Wang Yi-ming, Yu Shao-feng, Miao Xiu-xiu., 2014. Orthogonal design and numerical simulation of room and pillar configurations in fractured stopes [J]. Journal of Central South University, 21 (8), 3338-3344.

Wu Yong-ping, Xie Pan-shi, Ren Shi-guang., 2010a. Analysis of asymmetric structure around coal face of steeply dipping seam mining [J]. Journal of China Coal Society, 35 (2), 182-184, (in Chinese).

Wu Yong-ping, Xie Pan-shi, Wang Hong-wei, Ren Shi-guang., 2010b. Incline masonry structure around the coal face of steeply dipping seam mining [J]. Journal of China Coal Society 35 (8), 1252-1256 (in Chinese).

Wu Yong-ping, Zhang Yong-tao, Xie Pan-shi, Zeng You-fu., 2012. Study on surrounding rock deformation failure features and support technology of gateway in steep inclined seam [J]. Coal Engineering (1), 92-95 (in Chinese).

Xie Pan-shi, Wu Yong-ping, Wang Hong-wei, Gao Xi-cai, Ren Shi-guang, Zhen You-fu., 2012. Stability analysis of incline masonry structure and support around longwall mining face area in steeply dipping seam [J]. Journal of China Coal Society, 37 (8), 1275-1280 (in Chinese).

Yang Wei-ming, Li Lianchong, Li Xiao-jing, Wang Li-ge., 2014. Water outbursts in underground mining with steeply dipping coal seams: numerical simulations based on a mining case [J]. European Journal of Environmental and Civil Engineering 18 (5), 511-535.

Yin Guang-zhi, Wang Deng-ke, Zgang Wei-zhong., 2006. Mechanics model to deformation of covered rock strata and its application in deep mining of steep or inclined seam [J]. Journal of Chongqing University(Natural Science Edition) 29 (2), 79-82, (in Chinese).

Zaitsev SL., 1971. Physiological evaluation of the work of facemen and crew of the combine brigade in the Donbass mines with steeply sloping coal seams [J]. Gigiena Truda I Professional'nye Zabolevaniia, 15 (3), 24-27.

Zhang Zhi-pei, Liu Xiao-fei, Meng Ting., 2013. Analysis and evaluation on stability of the steep coal seam gob [J]. Advances in Civil and Industrial Engineering, 353, 1502-1506. 